\title{
Amphetamine-Induced Fos is Reduced in Limbic Cortical Regions but not in the Caudate or Accumbens in a Genetic Model of NMDA Receptor Hypofunction
}

\author{
Seiya Miyamoto*, 1,3 , John N Snouwaert'2, Beverly H Koller², Sheryl S Moy', Jeffrey A Lieberman' and \\ Gary E Duncan' \\ 'Department of Psychiatry and the Mental Health and Neuroscience Clinical Research Center, USA; ${ }^{2}$ Department of Medicine, University of \\ North Carolina, School of Medicine, Chapel Hill, NC, USA; ${ }^{3}$ Department of Neuropsychiatry, St Marianna University School of Medicine, \\ Kawasaki, Japan
}

\begin{abstract}
A mouse strain has been developed that expresses low levels of the NRI subunit of the NMDA receptor. These mice are a model of chronic developmental NMDA receptor hypofunction and may therefore have relevance to the hypothesized NMDA receptor hypofunction in schizophrenia. Many schizophrenia patients show exaggerated behavioral and neuronal responses to amphetamine compared to healthy subjects. Studies were designed to determine if the NRI-deficient mice would exhibit enhanced sensitivity to amphetamine. Effects of amphetamine on behavioral activation and Fos induction were compared between the NRI-deficient mice and wild-type controls. The NRI hypomorphic mice and controls exhibited similar locomotor activation after administration of amphetamine at $2 \mathrm{mg} / \mathrm{kg}$. The mutant mice showed slightly reduced peak locomotor activity and slightly increased stereotypy after $4 \mathrm{mg} / \mathrm{kg}$ amphetamine. There were no differences in Fos induction in response to amphetamine in the caudate putamen, nucleus accumbens, medial or central amygdala nuclei, or bed nucleus of the stria terminalis. However, amphetamine-induced Fos was substantially attenuated in the medial frontal (infralimbic) and cingulate cortices, basolateral amygdala, and in the lateral septum of the mutant mice. The results suggest a neuroanatomically selective activation deficit to amphetamine challenge in the NRI-deficient mice. Neuropsychopharmacology (2004) 29, 2180-2 I88, advance online publication, 29 September 2004; doi: I0.1038/sj.npp. I 300548
\end{abstract}

Keywords: NMDA receptor; NRI hypomorphic mice; schizophrenia; sensitization; amphetamine; psychostimulants

\section{INTRODUCTION}

Acute administration of $N$-methyl-D-aspartate (NMDA) receptor (NMDA-R) antagonists such as phencyclidine (PCP) and ketamine can produce positive, negative, and cognitive schizophrenia-like symptoms in healthy subjects (Luby et al, 1959; Davies and Beech, 1960; Krystal et al, 1994; Malhotra et al, 1996; Breier et al, 1997a). In patients with schizophrenia, NMDA antagonists can precipitate psychotic symptoms (Luby et al, 1959; Lahti et al, 1995; Malhotra et al, 1997). Such clinical observations have led to the hypothesis that reduced NMDA-R function could be a component of the pathophysiology of schizophrenia (Javitt and Zukin, 1991; Olney and Farber, 1995; Coyle, 1996).

\footnotetext{
* Correspondence: Dr S Miyamoto, Department of Neuropsychiatry, St Marianna University School of Medicine, Kawasaki 21 6-85 I I, Japan, Tel: +8I 044977 8III, Fax: + 8I 044976 334I,

E-mail: s2miya@marianna-u.ac.jp

Received 16 April 2004; revised 27 July 2004; accepted 27 July 2004 Online publication: 29 July 2004 at http://www.acnp.org/citations/ NPP07290404|76/default.pdf
}

Pharmacologic challenge tests with NMDA antagonists in humans and experimental animals have provided heuristic pharmacological models of schizophrenia (Newcomer et al, 1999; Krystal et al, 1994; Moghaddam and Adams, 1998; Duncan et al, 1998, 2000; Miyamoto et al, $2000,2001,2002)$. Since schizophrenia has, at least in part, neurodevelopmental abnormalities, and a chronic and progressive course in the majority of patients (Lieberman, 1999), the effects of chronically reduced NMDA-R function may better represent some facets of the disease (Jentsch and Roth, 1999; Olney and Farber, 1995; Miyamoto et al, 2003).

Functional NMDA receptors are composed of a common NR1 subunit and at least one of four subunits NR2 (NR2ANR2D) combined in an undetermined ratio to form a heteromeric configuration (Nakanishi, 1992; Monyer et al, 1992). A mouse strain with markedly reduced levels of the NMDA R1 (NR1) subunit of the NMDA-R (Mohn et al, 1999) has been developed that provides a model of NMDA receptor hypofunction potentially relevant to the pathophysiology of schizophrenia. While mice with complete deletion of the NR1 gene die within a day after birth (Li et al, 1994; 
Forrest et al, 1994), the NR1 hypomorphic mice maintain sufficient expression of the gene to allow them to thrive and survive to adulthood. The NR1-deficient mice display reduced locomotor habituation in a novel environment, increased stereotypic activity, deficits in social interactions, and reduced prepulse inhibition of acoustic startle (Mohn et al, 1999; Duncan et al, 2004). The behavioral alterations in the mutant mice are consistent with the notion that they provide an experimental model potentially relevant to the pathophysiology of schizophrenia (Mohn et al, 1999; Duncan et al, 2004).

A substantial proportion of patients with schizophrenia have an enhanced sensitivity to the behavioral effects of psychostimulants (Lieberman et al, 1997). A single administration of low doses of dopamine agonists, such as amphetamine and methylphenidate, that would not produce psychotic symptoms in healthy subjects, has been shown to exacerbate psychotic symptoms in patients with schizophrenia (Janowsky et al, 1973; Lieberman et al, 1987). Furthermore, brain imaging studies have shown that after an acute amphetamine challenge, striatal dopamine release is increased more in schizophrenia patients compared to controls (Abi-Dargham et al, 1998; Breier et al, 1997b; Laruelle et al, 1996), suggesting a dysregulated neuronal responsiveness to amphetamine in schizophrenia. It has been proposed that disinhibition of dopamine activity in the striatum is due to disturbed regulatory inputs in cortical and subcortical pathways involving both dopamine and glutamate (Carlsson et al, 1999; Laruelle et al, 1999; Weinberger et al, 2001). The pathophysiologic basis of this dysregulation, however, remains unclear.

The goal of the present study was to determine if chronically reduced NMDA-R function in the NR1 hypomorphic mice would affect amphetamine-induced functional responses in mice. Behavioral responses and alterations in the immediate early gene (IEG) c-fos product (Fos protein) were compared after acute amphetamine administration in wild-type and mutant mice with reduced NR1 subunit expression.

\section{METHODS AND MATERIALS}

\section{Animals}

A mouse line expressing reduced levels of the NR1 subunit of NMDA receptors was generated from a breeding colony originally established at the University of North Carolina as described previously (Mohn et al, 1999). Briefly, NR1deficient mice were generated from E14Tg2a embryonic stem cells in which one of the NR1 alleles was targeted in vitro by homologous recombination. A targeting construct, $\mathrm{Nr} 1^{\text {neo }}$, was designed in which a neomycin resistance gene was inserted into $\mathrm{Nr} 1$ intron 20. Targeted clones were used to create chimeric mice. Chimeric males were mated with female B6D2 mice to produce heterozygous mutants. The heterozygous mice were intercrossed and used to establish a breeding colony. All wild-type mice and mice homozygous for the mutant $\mathrm{Nr} 1$ gene were obtained from the intercross of identified heterozygotes. All mice were genotyped on the basis of Southern or PCR analysis of tail DNA (Mohn et al, 1999). The mice have markedly reduced levels of the NR1 subunit, without introducing point mutations or generating novel transcripts or proteins. There was a marked reduction in ${ }^{3} \mathrm{H}-\mathrm{MK}-801$ binding throughout the brain of the homozygous NR1 $-I-$ mice as described previously (Duncan et al, 2002a). The NR1 - /- mice and control $\mathrm{NR} 1+I+$ mice were created on a mixed genetic background consisting of alleles derived from 129/Ola, C57BL/6, and $\mathrm{DBA} / 2$. To increase the probability that alleles of various strains, including those linked to the $\mathrm{Nr} 1$, were included in both populations, mice that had inherited the wild-type 129 allele from the ES chimeras were used in establishing the breeding population (Mohn et al, 1999). Consistent with previous reports (Mohn et al, 1999), no gross neurological deficit was observed in the homozygous mice. The mice were housed in groups of two to six under a $12 \mathrm{~h}$ light-dark cycle with lights on at 0700 and had continuous access to food and water, and tested at 10-14 weeks of age. Experiments were performed on both wildtype $(+I+)$ mice and homozygous mutant $(-I-)$ littermates. Wild-type $(n=48)$ and NR1 $-/-$ groups $(n=48)$ were matched for age and gender in all experiments. Separate cohorts of mice were used for the locomotor activity and Fos induction studies described below. All animal use procedures were in strict accordance with the $\mathrm{NIH}$ Guide for the Care and Use of Laboratory Animals and were approved by the UNC Institutional Animal Care Committee.

\section{Assessment of Amphetamine-Induced Locomotor Activity}

The behavioral effects of amphetamine were assessed in photocell-based activity chambers. Activity measurements were taken under standardized environmental conditions, using a TruScan activity monitor (Coulbourn Instruments, Allentown, PA) with a $25.8 \times 25.8 \mathrm{~cm}^{2}$ Plexiglas chamber and a beam spacing of $1.52 \mathrm{~cm}$. Mice were acclimated to the room in which testing was carried out for at least $48 \mathrm{~h}$ prior to testing. Activity data were collected for wild-type $(n=24)$ and NR1-deficient $(n=24)$ mice over a 180 -min time course, beginning when the mouse was first placed in the testing chamber. Amphetamine ( 2 or $4 \mathrm{mg} / \mathrm{kg}$ ) or saline was injected i.p. $60 \mathrm{~min}$ after placing mice in the chambers. Amphetamine doses were chosen to match those used in the Fos induction studies described below. Data were collected in 5-min intervals at a sample interval of $100 \mathrm{~ms}$. The distance traveled in each 5-min interval was measured as the total of all vectored $X-Y$ coordinate changes. In addition, data were collected for fine movements indicative of stereotypic behaviors. For each group of mice, the mean $\pm S E M$ was calculated for each 5 -min time interval.

\section{Immunocytochemical Assessment of Fos-Like Immunoreactivity (Fos-LI)}

Mice were transported from the animal quarters to the laboratory and habituated to the experimental environment for seven to 10 days before the experiment. Mice were singly housed in a clear plastic cage $\left(26 \times 16 \times 13 \mathrm{~cm}^{3}\right)$ and handled each day. On the day of the experiment, mice were injected with amphetamine ( 2 and $4 \mathrm{mg} / \mathrm{kg}$ ) or saline i.p. and were returned to their home cages. The doses of 
amphetamine were chosen based on preliminary studies showing regionally selective induction of Fos and a more robust response for the higher dose. All experiments were carried out between 1100 and 1500 to avoid the effect of circadian rhythm.

Immunocytochemical procedures were performed according to the previously published protocols (Duncan et al, 1993, 1996, 1998). At $2 \mathrm{~h}$ after amphetamine or saline injection, mice were anesthetized with chloral hydrate $(400 \mathrm{mg} / \mathrm{kg}$, i.p.). This time point was chosen because it is near the 'peak' of Fos expression reported after amphetamine administration (Engber et al, 1998; Turgeon and Roche, 1999; Mead et al, 1999), and found in preliminary studies. Mice were perfused through the left cardiac ventricle with ice-cold $100 \mathrm{mM}$ sodium phosphate-buffered saline (PBS, $\mathrm{pH}=7.4$ ) for $1 \mathrm{~min}$, at a rate of $3 \mathrm{ml} / \mathrm{min}$, followed by $4 \%$ paraformaldehyde in PBS for $7 \mathrm{~min}$. Brains were removed immediately after perfusion and postfixed in $4 \%$ paraformaldehyde overnight. Coronal sections $(50 \mu \mathrm{m})$ were cut from each brain using a vibratome and placed in PBS contained in 24-well tissue culture dishes. Sections were treated with 5\% normal goat serum (Vector Laboratories, Burlingame, CA) and $0.1 \%$ Triton X-100 in PBS for $30 \mathrm{~min}$ and then were incubated for $48-72 \mathrm{~h}$ at $4{ }^{\circ} \mathrm{C}$ with a rabbit polyclonal Fos antiserum (1:10 000 dilution) raised against a synthetic peptide corresponding to amino acids $2-17$ of a conserved region of mouse and human c-fos gene product (Biogenesis Inc., Brentwood, NH). Since it is uncertain whether this antibody recognizes Fos-related antigens as well as Fos, results are described as Fos-LI. After incubation with the Fos antiserum, sections were processed through three rinses of PBS and incubated for $1 \mathrm{~h}$ with biotinylated antirabbit IgG (Vector Laboratories). After three rinses with PBS, the sections were incubated with avidin-biotin complex (Vectastain Elite ABC Kit; Vector Laboratories) for $1 \mathrm{~h}$. After an additional three rinses with PBS, sections were placed in a solution containing $0.05 \% 3,3^{\prime}$-diaminobenzidene tetrahydrochloride, $0.005 \%$ cobalt chloride, $0.008 \%$ nickel ammonium sulfate, and $0.02 \%$ hydrogen peroxide.

\section{Quantification of Fos-LI}

Cells exhibiting nuclear staining for Fos-LI in a $250 \times$ $250 \mu \mathrm{m}^{2}$ area of the selected brain regions were counted at magnification of $\times 200$ by an experimenter blind to the treatment group. From preliminary studies, 12 regions of interest were chosen based on consistent and robust induction of Fos in response to amphetamine. Sections were selected that contained the regions of interest from macroscopic features of the sections. The locations of the areas used within each brain region for assessing FosLI-positive cells were taken from Franklin and Paxinos (1997), and are shown in Figure 1. Counts were taken bilaterally in two sections per mouse for each region. For the core and shell of the nucleus accumbens and paraventricular anterior thalamic nucleus, cells were counted in a $125 \times 250 \mu \mathrm{m}^{2}$ area due to the small size of the regions. For the posterior lateral division of bed nucleus of stria terminalis, nuclei of the amygdala, and midline thalamic nuclei, cells were counted in the defined nuclear
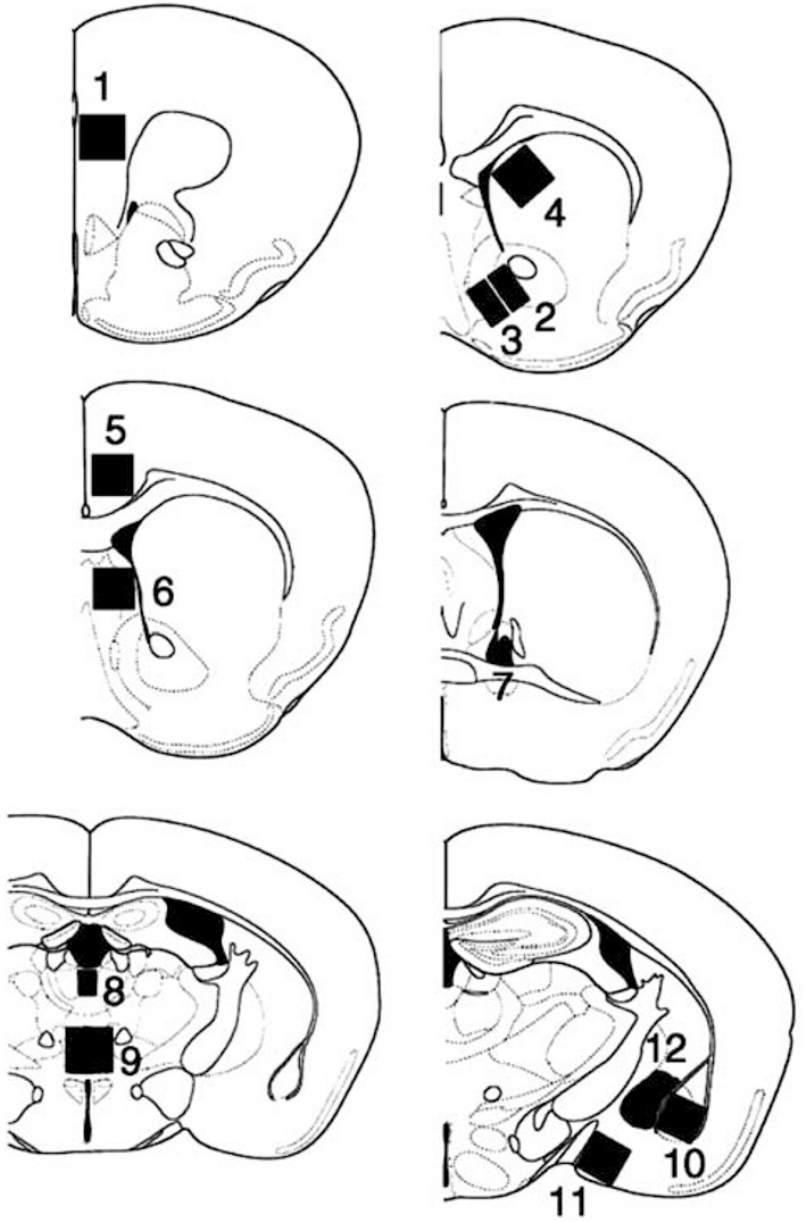

Figure I Diagrams of representative coronal sections used for the quantification of Fos-LI-positive neurons in the medial frontal cortex (I), core (2) and shell (3) of the nucleus accumbens, dorsomedial part of the caudate putamen (4), cingulate cortex (5), lateral septal nucleus (6), posterior lateral division of bed nucleus of stria terminalis (7), paraventricular anterior thalamic nucleus (8), midline thalamic nuclei (9), basolateral nucleus of amygdala ( 10$)$, medial amygdaloid nucleus ( $\mathrm{I} \mid$ ), and central nucleus of amygdala (12). Drawings are from Franklin and Paxinos (1997).

areas clearly apparent from the background nonspecific staining of the sections.

\section{Statistical Analysis}

Data for activity and Fos cell counts were analyzed by repeated measures ANOVA using StatView (version 5.0.1, SAS Institute Inc.), with time and brain region as repeated measures for motoric and Fos responses, respectively. For activity, time measures included interval (5-min bins across the $3 \mathrm{~h}$ of testing) and hour (preinjection hour, postinjection first hour, and postinjection second hour). In addition to the overall ANOVA, separate repeated measures ANOVAs were performed for each hour, with the factors of genotype and interval. For the Fos-LI results, separate two-way ANOVAs, with the factors of genotype and amphetamine treatment, were conducted on the data for each brain region. Fisher's protected least-significant difference tests were used for comparing group means only when a significant F-value was determined. For all comparisons, significance was set at $p<0.05$. 


\section{RESULTS}

\section{Behavioral Effects of Acute Saline or Amphetamine} Administration in Wild-Type and NR1-Deficient Mice

Significant overall effects of genotype were evident in the test with an acute saline challenge for the locomotor activity $(\mathrm{F}(1,14)=9.607, p=0.0078)$ and number of fine movements $(\mathrm{F}(1,14)=5.345, p=0.0365)$. Further analyses of $1 \mathrm{~h}$ intervals in the activity chambers revealed that there were no significant differences between the experimental groups in the first hour of the session, before the saline injection. At the time of saline or amphetamine injection (ie, $1 \mathrm{~h}$ after placement of mice in the chambers), the levels of activity were similar for the wild-type and mutant mice. However, during the hour following the saline injection, the NR1deficient mice had higher levels of locomotor activity than the wild-type animals $(\mathrm{F}(1,14)=4.670, p=0.0485)$. In the second hour post-saline injection, the NR1 -Igroup maintained the increased levels of locomotion (main effect of genotype, $\mathrm{F}(1,14)=10.715, p=0.0055$; and genotype $\times$ interval interaction, $\mathrm{F}(11,154)=2.383, p=0.0094$ ) and also evidenced higher levels of fine movements $(\mathrm{F}(1,14)=9.248, p=0.0088)$.

At the $2 \mathrm{mg} / \mathrm{kg}$ dose of amphetamine, there were no significant differences between the NR1 $+I+$ and NR1 $-I-$ mice in the maximal activation or in the time course of the activation for the locomotor measure (Figure 2b). In contrast, the NR1-deficient mice showed significantly higher numbers of fine movements, in comparison to the wildtype group (Figure $3 b ; \mathrm{F}(1,14)=10.758, p=0.0055$ ). Further analyses indicated that the differences in stereotypic activity were not evident for the preinjection hour or the first postinjection hour of the test session, but only emerged in the second hour after drug administration (main effect of genotype, $\mathrm{F}(1,14)=7.862, \quad p=0.0141 ;$ and genotype $\times$ interval interaction, $\mathrm{F}(11,154)=2.257, p=0.0142)$. This pattern was similar to the increased numbers of fine movements evident in the NR1 $-I-$ mice during the second hour after treatment with saline.

At the higher amphetamine dose $(4 \mathrm{mg} / \mathrm{kg}$; Figures $2 \mathrm{c}$ and $3 c)$, an overall repeated measures ANOVA revealed significant interactions between genotype and interval for both activity measures (locomotion, $\mathrm{F}(11,154)=1.997$, $p=0.0321 ;$ and fine movements, $\mathrm{F}(11,154)=4.030$, $p<0.0001)$, and between genotype, hour, and interval (locomotion, $\mathrm{F}(22,308)=1.726, p=0.0240$; and fine movement, $\mathrm{F}(22,308)=2.611, p=0.0001)$. Significant differences between the two experimental groups in the locomotor activity were only evident in the hour immediately following the administration of amphetamine, at which time the NR1 mutant animals had a slightly blunted response to the initial stimulant drug effects (genotype $\times$ interval interaction, $\mathrm{F}(11,154)=2.796, \quad p=0.0024)$. A different pattern was observed for the fine movements measure, wherein the NR1 -I- group had higher levels during the first hour of the test session (genotype $\times$ interval interaction, $\mathrm{F}(11,154)=3.531, p=0.0002)$ and during the hour following drug administration (genotype $\times$ interval interaction, $\mathrm{F}(11,154)=4.135, p<0.0001)$. The differences between the two genotypes in both locomotion and fine movements were no longer present during the last hour of the test session.
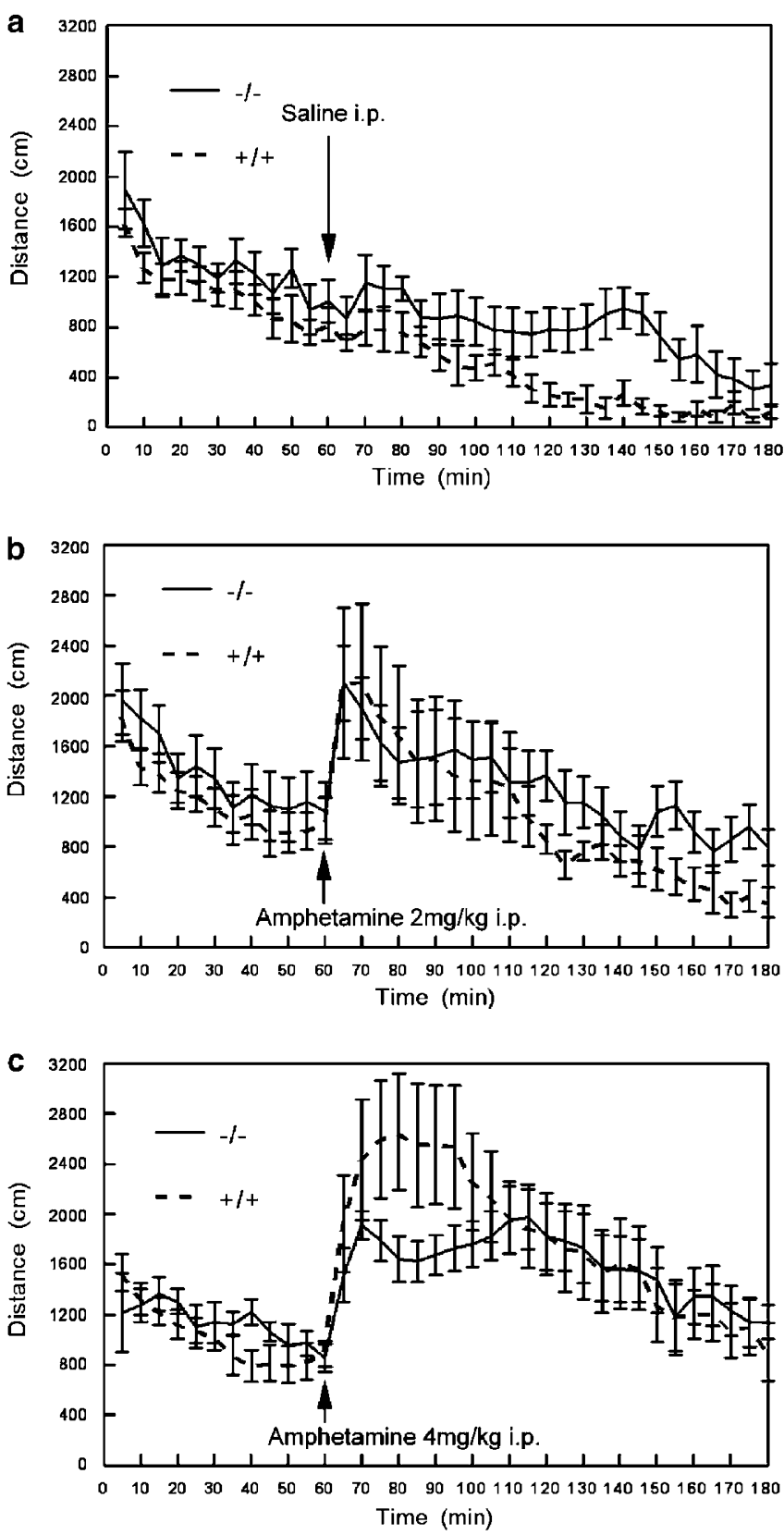

Figure 2 Locomotor activity after amphetamine administration in NRI $+1+$ and NRI $-/-$ mice. Mice were injected with saline (a) or amphetamine (b, $2 \mathrm{mg} / \mathrm{kg} ; \mathrm{c}, 4 \mathrm{mg} / \mathrm{kg}$ ) $60 \mathrm{~min}$ after placement in the activity chambers as indicated by arrows. Data are means \pm SEMs.

\section{Effects of Amphetamine on Fos-LI in Wild-Type and NR1-Deficient Mice}

An overall repeated measures ANOVA revealed highly significant effects of amphetamine treatment $(\mathrm{F}(2,42)=$ $24.330, p<0.0001)$ and brain region $(F(11,462)=24.168$, $p<0.0001)$ on levels of Fos-LI. While genotype did not have an overall effect $(\mathrm{F}(1,42)=3.107, p=0.0852)$, there was a significant interaction between genotype and brain region $(\mathrm{F}(11,462)=2.669, p<0.0001)$, suggesting that the impact of NR1 deficiency varied across the different areas of the brain. Changes in Fos-LI following the administration of 

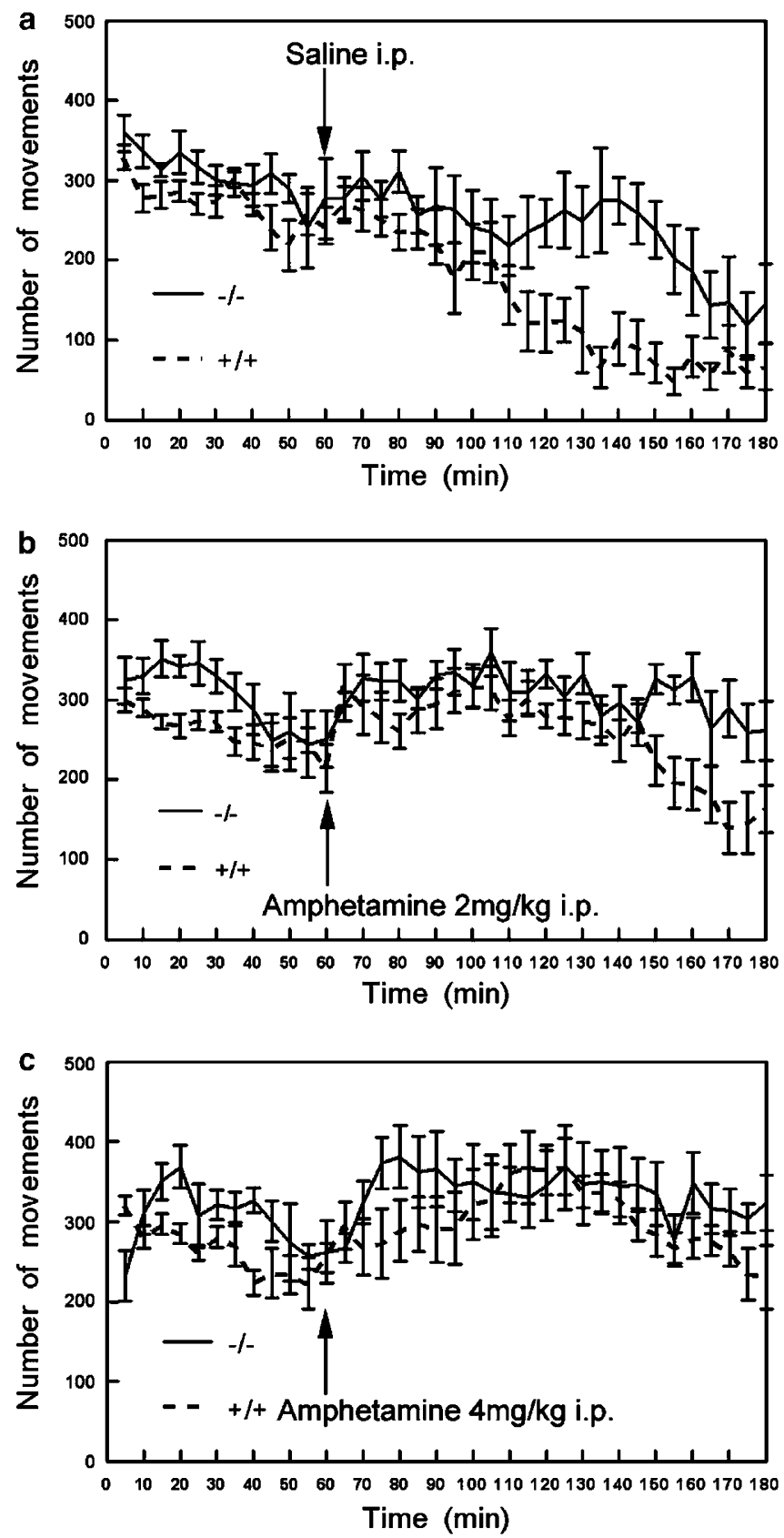

Figure 3 Fine movements after amphetamine administration in NRI $+/+$ and NRI -/- mice. Mice were injected with saline (a) or amphetamine (b, $2 \mathrm{mg} / \mathrm{kg} ; \mathrm{c}, 4 \mathrm{mg} / \mathrm{kg}$ ) $60 \mathrm{~min}$ after placement in the activity chambers as indicated by arrows. Data are means \pm SEMs.

amphetamine were also dependent on brain region (treatment $\times$ brain region interaction, $\mathrm{F}(22,462)=12.587$, $p<0.0001)$.

Repeated measures ANOVAs showed that after the saline injection, there were no significant differences between the wild-type and NR1 hypomorphic mice in Fos-LI induction (Figure 4), although levels varied with brain region $(\mathrm{F}(11,165)=12.517, p<0.0001)$. Significant effects of genotype emerged for both doses of amphetamine $(2 \mathrm{mg} / \mathrm{kg}$; significant main effect of genotype, $\mathrm{F}(1,11)=29.898$, $p<0.0009$, and brain region, $\mathrm{F}(11,77)=20.006, p<0.0001$;
$4 \mathrm{mg} / \mathrm{kg}$, significant effect of brain region, $\mathrm{F}(11,220)=$ 22.372, $p<0.0001$, and significant genotype $\times$ brain region interaction, $\mathrm{F}(11,220)=3.511, p=0.0002)$.

These results suggested that there was a differential impact of the amphetamine treatment in the NR1-deficient mice, but this effect was only evident in some of the surveyed brain regions. Therefore, separate analyses were run for each area of the brain, looking at both genotype and treatment effects. As depicted in Table 1, amphetamine treatment led to significant increases in Fos-LI in every brain region surveyed (representative immunocytochemically stained sections are shown in Figures 5 and 6). However, the effects of amphetamine were blunted in the mutant mice, in comparison to the wild-type controls, in the medial frontal cortex (infralimic cortex), cingulate cortex, lateral septal nucleus, and basolateral nucleus of the amygdala (Figure 4; see Table 1 for F-values).

\section{DISCUSSION}

Many patients with schizophrenia exhibit enhanced sensitivity to psychostimulants (Lieberman et al, 1997). The present study was designed to determine if NR1 hypomorphic mice could model this behavioral phenotype-associated enhanced dopaminergic sensitivity. Acute behavioral responses to $2 \mathrm{mg} / \mathrm{kg}$ amphetamine were similar between wild-type and NR1 hypomorphic mice. At $4 \mathrm{mg} / \mathrm{kg}$ amphetamine, the peak locomotor activation induced by the stimulant was slightly lower in the NR1 hypomorphic mice and stereotypic behaviors slightly higher. The reduced peak locomotor response to amphetamine in the NR1 -/- mice is probably related to the emergence of greater stereotypic behaviors for the higher amphetamine dose. It will be important in future studies to examine the effects of lower doses of amphetamine to better assess behavioral sensitivity in the NR1 $-/-$ mice.

The NR1 - /- mice tested in the present study did not exhibit increased activity in comparison to controls during the first hour after placement in the activity chambers. The main differences between the mutant and wild-type mice were seen during the last hour of the 3-h testing period. Different cohorts of the NR1 $-/-$ mice we have examined show variations in the patterns of locomotor activity, with some exhibiting increased activity relative to controls at early times after placement in the activity chamber, and others showing differences only at later times. The most consistent effect of the NR1 hypomorphic mutation on locomotor activity in different cohorts of mice is reduced habituation. We have seen this pattern of reduced habituation in many groups of mice that did not receive saline injections during the behavioral testing.

Amphetamine-induced Fos in most subcortical structures was similar for the wild-type and mutant animals at both doses examined. However, the NR1-deficient mice exhibited attenuated Fos induction in response to amphetamine in the medial frontal and cingulate cortices, basolateral amygdala, and in the lateral septum. These data clearly show that NR1 hypomorphic mice do not provide a model for enhanced sensitivity to amphetamine with regard to the specific parameters assessed. Accordingly, the mice do not model 


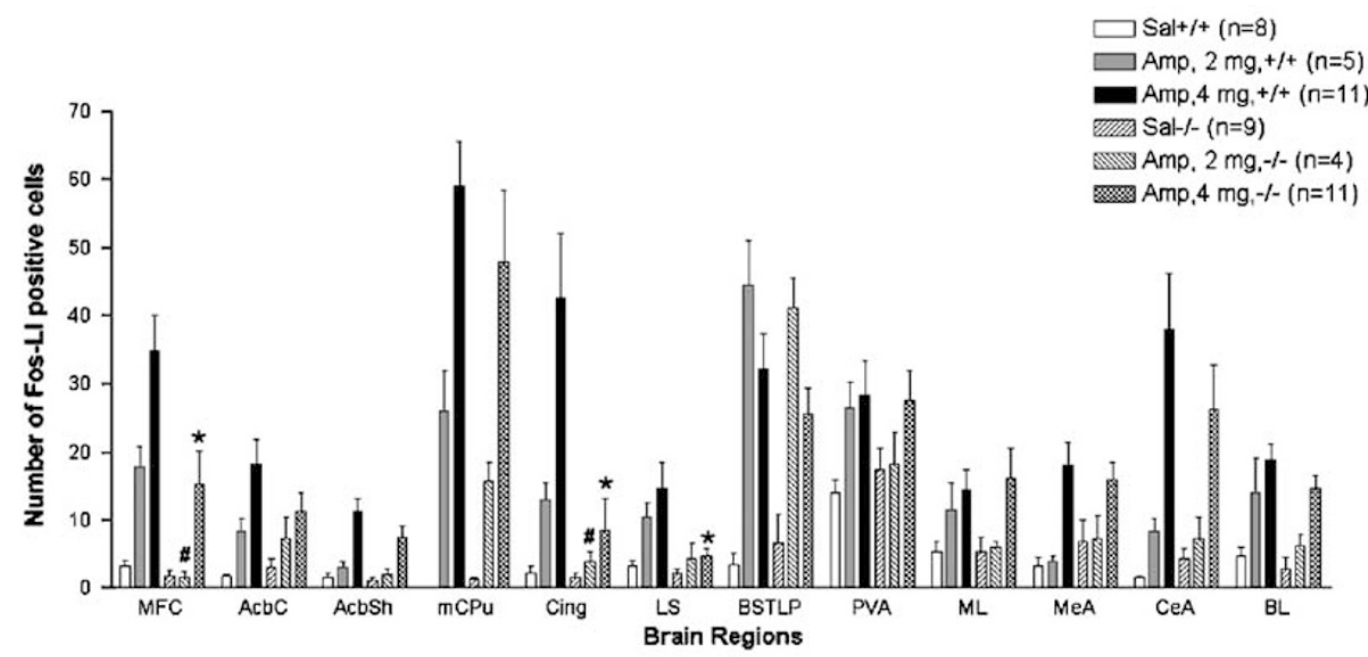

Figure 4 Effects of amphetamine on Fos induction in wild-type $(+/+)$ and NRI-deficient $(-/-)$ mice. Data are means \pm SEMs. ${ }^{\#} p<0.05$ compared to $2 \mathrm{mg} / \mathrm{kg}$ of amphetamine in wild-type $(+/+)$ mice. $* 0<0.05$ compared to $4 \mathrm{mg} / \mathrm{kg}$ of amphetamine in wild-type $(+/+)$ mice. Abbreviations: MFC, medial frontal cortex; AcbC, core of the nucleus accumbens; AcbSh, shell of the nucleus accumbens; mCPu, dorsomedial part of the caudate putamen; Cing, cingulate cortex; LS, lateral septal nucleus; BSTLP, posterior lateral division of bed nucleus of stria terminalis; PVA, paraventricular anterior thalamic nucleus; ML, midline thalamic nuclei; MeA, medial amygdaloid nucleus; CeA, central nucleus of amygdala; BL, basolateral nucleus of amygdala.

Table I F-Values for the Statistical Analysis of Genotype and Amphetamine Effects on Fos Expression in Different Regions of Brain

\begin{tabular}{|c|c|c|c|}
\hline Brain region & Genotype, $F(1,42)$ & Amphetamine treatment, $F(2,42)$ & Interaction, $\mathbf{F}(2,42)$ \\
\hline MFC & $1 \mathrm{I} .824, p=0.0013^{*}$ & $|9.002, p<0.000|^{*}$ & $3.074, p=0.0568$ \\
\hline AcbC & $0.828, p=0.3679$ & || $.85|, p<0.000| *$ & $1.383, p=0.2620$ \\
\hline AcbSh & $1.465, p=0.2330$ & $|7.86|, p<\left.0.000\right|^{*}$ & $0.765, p=0.4719$ \\
\hline $\mathrm{mCPu}$ & $1.149, p=0.2899$ & $32.769, p<\left.0.000\right|^{*}$ & $0.478, p=0.6232$ \\
\hline Cing & $7.506, p=0.0090 *$ & $9.692, p=0.0003^{*}$ & $4.833, p=0.0129 *$ \\
\hline BSTLP & $0.323, p=0.5729$ & $28.902, p<0.000 I^{*}$ & $0.658, p=0.5230$ \\
\hline PVA & $0.264, p=0.6099$ & $4.757, p=0.0137 *$ & $0.633, p=0.5361$ \\
\hline ML & $0.161, p=0.6904$ & $5.091, p=0.0105^{*}$ & $0.422, p=0.6459$ \\
\hline $\mathrm{MeA}$ & $0.411, p=0.5248$ & $|2.127, p<0.000|^{*}$ & $0.687, p=0.5087$ \\
\hline $\mathrm{CeA}$ & $0.380, p=0.5410$ & $|5.3| 6, p<0.000 \mid *$ & $0.888, p=0.4190$ \\
\hline
\end{tabular}

* $p<0.05$. For abbreviations, see legend to Figure 4 .

the enhanced dopaminergic sensitivity observed in a substantial portion of patients with schizophrenia.

It is unclear as to why a reduction in cortical Fos induction in some brain regions was observed in the NR1 $-I-$ mice, with minimal changes in the behavioral responses to amphetamine, especially for the $2 \mathrm{mg} / \mathrm{kg}$ dose of the drug. The data suggest that amphetamine-induced activation of Fos-related mechanisms in the medial frontal and cingulate cortices, and in the lateral septum and basolateral amygdala, can be dissociated from the locomotor activity.

It was surprising that amphetamine-induced Fos was differentially effected in the cortex and striatum of the NR1 hypomorphic mice, since equivalent reduction in ${ }^{3} \mathrm{H}-\mathrm{MK}$ 801 binding was found in striatal and cortical regions (Duncan et al, 2002). Disruption of NMDA-R function by acute challenge with MK-801 is consistently reported to decrease the effects of amphetamine on striatal c-fos, Fos, and zif/268 expression, suggesting possible involvement of NMDA-R in the effects of amphetamine in this region (Snyder-Keller, 1991; Ohno et al, 1994; Wang et al, 1994; Konradi et al, 1996). It is possible that compensatory alterations in dopamine-glutamate interactions occur in the striatum of NR1 hypomorphic mice that make the Fos response to dopaminergic activation less dependent on NMDA receptor activation.

Assessment of the effects of NMDA antagonists on amphetamine-induced Fos induction in the medial frontal and cingulate cortices has been complicated by the fact that NMDA antagonists themselves increase Fos in these regions (Dragunow and Faull, 1990; Duncan et al, 1998). The present findings suggest a role of NMDA receptors in 

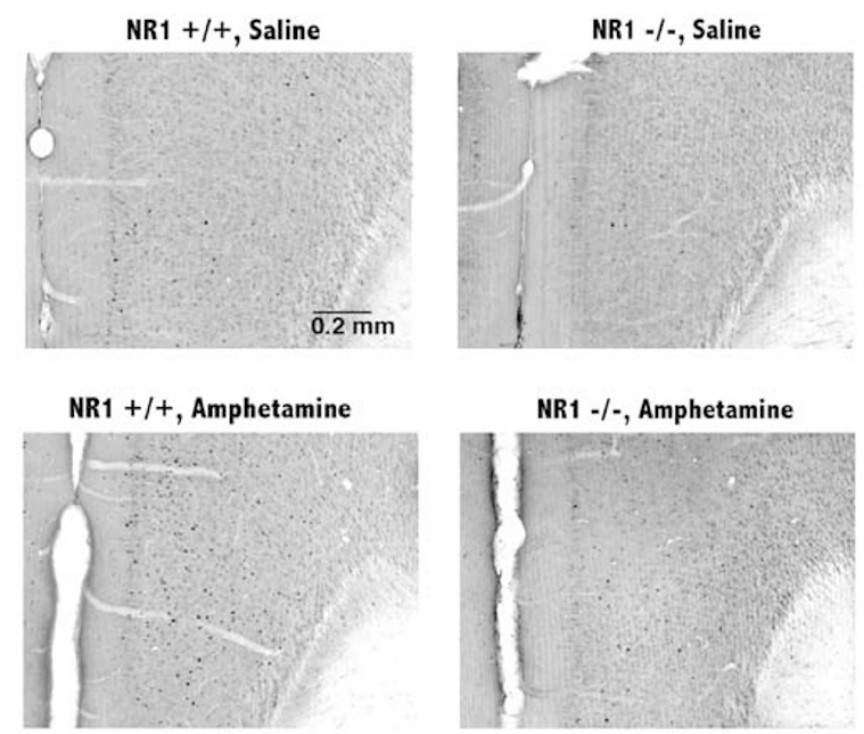

Figure $5 \mathrm{NRI}(-/-)$ mice display attenuated Fos-LI expression induced by amphetamine in the medial frontal cortex. Representative immunocytochemical staining for Fos-LI in the medial frontal cortex after treatment with saline or $4 \mathrm{mg} / \mathrm{kg}$ of amphetamine in both wild-type $(+/+)$ and NRI $(-/-)$ mice.
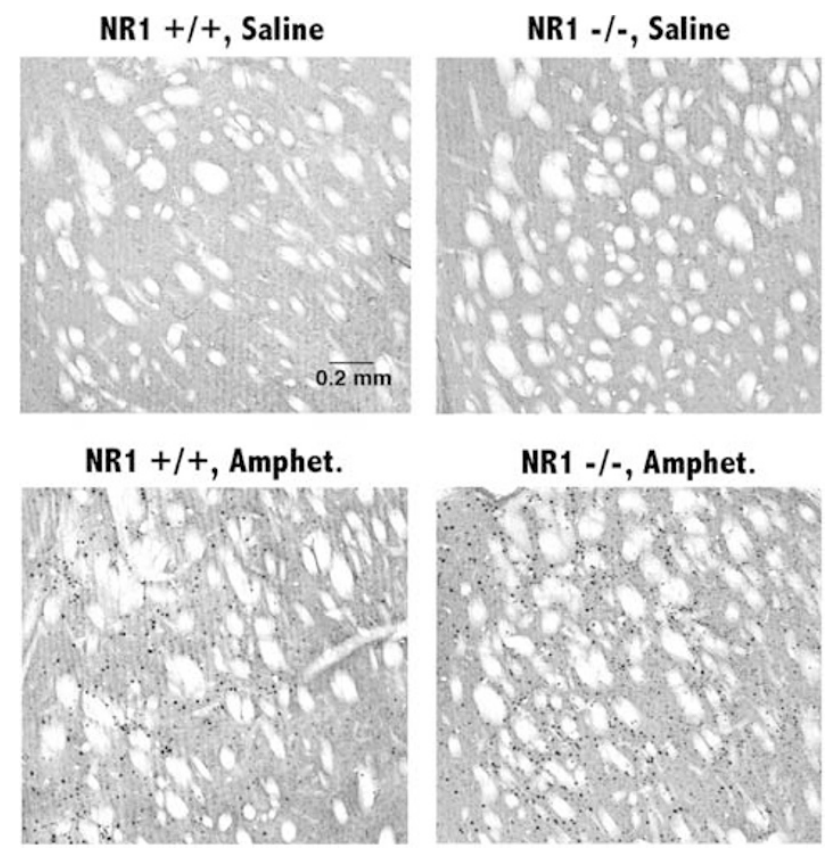

Figure $6 \mathrm{NRI}(-/-)$ mice display equivalent Fos-LI expression induced by amphetamine in the striatum. Representative immunocytochemical staining for Fos-LI in the dorsomedial part of the caudate putamen after treatment with saline or $4 \mathrm{mg} / \mathrm{kg}$ of amphetamine in both wild-type $(+/+)$ and $\mathrm{NRI}(-/-)$ mice. Abbreviation: Amphet.: amphetamine.

amphetamine-induced Fos in the medial frontal and cingulate cortices. The differential effects observed in the cortex and striatum in the NR1 hypomorphic mice after amphetamine suggest that cortical and striatal NMDAdopamine receptor interactions are affected differently in cortical and striatal regions of the mutant mice.
Amphetamine is well known to induce robustly dopamine release in the striatum (Snyder et al, 1972; Zetterstrom et al, 1983; Carboni et al, 1989; Kuczenski and Segal, 1989). The striatal dopaminergic system in NR1 hypomorphic mice, including basal, unstimulated concentration of extracellular dopamine, the tissue contents of dopamine, and its metabolites, appears to be fairly intact (Mohn et al, 1999). In contrast to the apparent lack of effect of the NR1 hypomorphic mutation on striatal dopamine release, chronic treatment with PCP enhanced amphetamineinduced dopamine release in the striatum and medial frontal cortex (Balla et al, 2001; Balla et al, 2003). It will be of interest to assess dopamine release in the NR1-deficient mice in response to amphetamine in future studies.

It is possible that compensatory changes in non-NMDA glutamate receptors influence the action of the psychostimulant in our mice. However, in the NR1-deficient mice, no compensatory changes in densities of non-NMDA ionotropic glutamate receptors were found (Duncan et al, 2002). Future studies measuring the densities and function of dopamine and other glutamate receptors are required to determine potential adaptive neurochemical mechanisms of the mutant mice.

In addition to dopamine, amphetamine also induces the release of norepinepherine and serotonin (Munoz et al, 2003; Shoblock et al, 2004). Further study will be required to determine the specific neurotransmitter mechanisms responsible for the observed deficits in amphetamine-induced Fos induction in the NR1 $-/-$ mice.

Previous studies reporting the interaction between amphetamine and NMDA-R antagonists in terms of IEG gene induction and behavioral responses yielded somewhat disparate results. For example, amphetamine-induced behavioral responses, including hyperactivity and stereotypies, can be either enhanced (Balla et al, 2003; Turgeon and Roche, 1999), inhibited (Greenberg and Segal, 1985), or unchanged (Wang et al, 1994) by NMDA-R antagonists such as PCP in rodents. The different effects observed probably relate to different doses, patterns of exposure, and the time interval examined after the administration of the NMDA antagonists. As mentioned earlier, in the striatum, MK-801 has inhibitory effects on amphetamine-induced Fos (Snyder-Keller, 1991; Ohno et al, 1994; Wang et al, 1994). PCP has a delayed effect of enhancing amphetamineinduced Fos when rats are tested the day after acute or subchronic (4 days) treatment with the NMDA antagonists (Turgeon and Roche, 1999; Turgeon and Case, 2001). The different effects of NMDA-R antagonists on behaviors and IEG induction thus appear to be dependent on the specific paradigms used (Turgeon and Case, 2001).

Although the present results indicate that the NR1 hypomorphic mice do not model enhanced dopaminergic sensitivity, the mice may still be a relevant model for certain phenotypes of schizophrenia. It should be noted that enhanced sensitivity to dopaminergic stimulants is observed in only $40-60 \%$ of patients with schizophrenia (Lieberman et al, 1987). These findings suggest that a substantial portion of patients do not exhibit a phenotype consistent with dopamine supersensitivity. We recently demonstrated that the NR1 hypomorphic mice exhibit deficits in prepulse inhibition of acoustic startle and showed marked deficits in two different paradigms of species typical 
social interactions (Duncan et al, 2004). Such data, and the originally observed behaviors of the mice by Mohn et al (1999), are consistent with phenotypes observed in schizophrenia patients. The mutant mice may thus provide a useful model to explore neurobiological mechanisms related to certain behavioral phenotypes associated with reduced NMDA receptor function in the context of the NMDA receptor hypofunction of schizophrenia.

\section{ACKNOWLEDGEMENTS}

We thank Diane L Baron, Tonja Troxler, Eric Campbell, MyTrang S Nguyen, and Brett A Feeney for excellent experimental assistance, and the NDRC Mouse Behavioral Phenotyping Laboratory for statistical consultation. This work was supported by MH063398, the UNC Silvio O Conte Center for the Neuroscience of Mental Disorders (MH064065), and NARSAD.

\section{REFERENCES}

Abi-Dargham A, Gil R, Krystal J, Baldwin RM, Seibyl JP, Bowers M et al (1998). Increased striatal dopamine transmission in schizophrenia: confirmation in a second cohort. Am J Psychiatry 155: 761-767.

Balla A, Hashim A, Burch S, Javitt DC, Lajtha A, Sershen H (2001). Phencyclidine-induced dysregulation of dopamine response to amphetamine in prefrontal cortex and striatum. Neurochem Res 26: 1001-1006.

Balla A, Sershen H, Serra M, Koneru R, Javitt DC (2003). Subchronic continuous phencyclidine administration potentiates amphetamine-induced frontal cortex dopamine release. Neuropsychopharmacology 28: 34-44.

Breier A, Malhotra AK, Pinals DA, Weisenfeld NI, Pickar D (1997a). Association of ketamine-induced psychosis with focal activation of the prefrontal cortex in healthy volunteers. Am J Psychiatry 154: 805-811.

Breier A, Su TP, Saunders R, Carson RE, Kolachana BS, de Bartolomeis A et al (1997b). Schizophrenia is associated with elevated amphetamine-induced synaptic dopamine concentrations evidence from a novel positron emission tomography method. Proc Natl Acad Sci USA 94: 2569-2574.

Carboni E, Imperato A, Perezzani L, Di Chiara G (1989). Amphetamine, cocaine, phencyclidine and nomifensine increase extracellular dopamine concentrations preferentially in the nucleus accumbens of freely moving rats. Neuroscience 28: 653-661.

Carlsson A, Waters N, Carlsson ML (1999). Neurotransmitter interactions in schizophrenia-therapeutic implications. Biol Psychiatry 46: 1388-1395.

Coyle JT (1996). The glutamatergic dysfunction hypothesis for schizophrenia. Harv Rev Psychiatry 3: 241-253.

Davies BM, Beech HR (1960). The effect of 1-arylcyclohexylamine (sernyl) on twelve normal volunteers. J Ment Sci 106: 912-924.

Dragunow M, Faull RL (1990). MK801 induces c-fos protein in thalamic and neocortical neurons of rat brain. Neurosci Lett 113: 144-150.

Duncan GE, Johnson KB, Breese GRT (1993). Topographic patterns of brain activity in response to swim stress: assessment by 2deoxyglucose uptake and expression of Fos-like immunoreactivity. J Neurosci 13: 3932-3943.

Duncan GE, Knapp DJ, Breese GR (1996). Neuroanatomical characterization of Fos induction in rat behavioral models of anxiety. Brain Res 713: 79-91.
Duncan GE, Miyamoto S, Gu H, Lieberman JA, Koller BH, Snouwaert JN (2002). Alterations in regional brain metabolism in genetic and pharmacological models of reduced NMDA receptor function. Brain Res 951: 166-176.

Duncan GE, Miyamoto S, Leipzig JN, Lieberman JA (2000). Comparison of the effects of clozapine, risperidone, and olanzapine on ketamine-induced alterations in regional brain metabolism. J Pharmacol Exp Ther 293: 8-14.

Duncan GE, Moy SS, Knapp DJ, Mueller RA, Breese GR (1998). Metabolic mapping of the rat brain after subanesthetic doses of ketamine: potential relevance to schizophrenia. Brain Res 787: 181-190.

Duncan GE, Moy SS, Perez A, Eddy DM, Zinzow WM, Lieberman JA et al (2004). Deficits in sensorimotor gating and tests of social behavior in a genetic model of reduced NMDA receptor function. Behav Brain Res 153: 507-519.

Engber TM, Koury EJ, Dennis SA, Miller MS, Contreras PC, Bhat RV (1998). Differential patterns of regional c-Fos induction in the rat brain by amphetamine and the novel wakefulnesspromoting agent modafinil. Neurosci Lett 241: 95-98.

Forrest D, Yuzaki M, Soares HD, Ng L, Luk DC, Sheng M et al (1994). Targeted disruption of NMDA receptor 1 gene abolishes NMDA response and results in neonatal death. Neuron 13: 325-338.

Franklin KBJ, Paxinos G (1997). The Mouse Brain in Stereotaxic Coordinates. Academic Press: San Diego.

Greenberg BD, Segal DS (1985). Acute and chronic behavioral interactions between phencyclidine (PCP) and amphetamine: evidence for a dopaminergic role in some PCP-induced behaviors. Pharmacol Biochem Behav 23: 99-105.

Janowsky DS, el-Yousel MK, Davis JM, Sekerke HJ (1973). Provocation of schizophrenic symptoms by intravenous administration of methylphenidate. Arch Gen Psychiatry 28: $185-191$.

Javitt DC, Zukin SR (1991). Recent advances in the phencyclidine model of schizophrenia. Am J Psychiatry 148: 1301-1308.

Jentsch JD, Roth RH (1999). The neuropsychopharmacology of phencyclidine: from NMDA receptor hypofunction to the dopamine hypothesis of schizophrenia. Neuropsychopharmacology 20: 201-225.

Konradi C, Leveque JC, Hyman SE (1996). Amphetamine and dopamine-induced immediate early gene expression in striatal neurons depends on postsynaptic NMDA receptors and calcium. J Neurosci 16: 4231-4239.

Krystal JH, Karper LP, Seibyl JP, Freeman GK, Delaney R, Bremner JD et al (1994). Subanesthetic effects of the noncompetitive NMDA antagonist, ketamine, in humans. Psychotomimetic, perceptual, cognitive, and neuroendocrine responses. Arch Gen Psychiatry 51: 199-214.

Kuczenski R, Segal D (1989). Concomitant characterization of behavioral and striatal neurotransmitter response to amphetamine using in vivo microdialysis. J Neurosci 9: 2051-2065.

Lahti AC, Koffel B, LaPorte D, Tamminga CA (1995). Subanesthetic doses of ketamine stimulate psychosis in schizophrenia. Neuropsychopharmacology 13: 9-19.

Laruelle M, Abi-Dargham A, Gil R, Kegeles L, Innis R (1999). Increased dopamine transmission in schizophrenia: relationship to illness phases. Biol Psychiatry 46: 56-72.

Laruelle M, Abi-Dargham A, Van Dyck CH, Gil R, D'Souza CD, Erdos J et al (1996). Single photon emission computerized tomography imaging of amphetamine-induced dopamine release in drug-free schizophrenic subjects. Proc Natl Acad Sci USA 93: 9235-9240.

Li Y, Erzurumlu RS, Chen C, Jhaveri S, Tonegawa S (1994). Whisker-related neuronal patterns fail to develop in the trigeminal brainstem nuclei of NMDAR1 knockout mice. Cell 76: 427-437. 
Lieberman JA (1999). Is schizophrenia a neurodegenerative disorder?: a clinical and pathophysiological perspective. Biol Psychiatry 46: 729-739.

Lieberman JA, Kane JM, Alvir JAJ (1987). Provocative tests with psychostimulant drugs in schizophrenia. Psychopharmacology 91: 415-433.

Lieberman JA, Sheitman BB, Kinon BJ (1997). Neurochemical sensitization in the pathophysiology of schizophrenia deficits and dysfunction in neuronal regulation and plasticity. Neuropsychopharmacology 17: 205-229.

Luby ED, Cohen BD, Rosenbaum G, Gottilieb JS, Kelley R (1959). Study of a new schizophrenomimeitc drug - sernyl. Arch Neurol Psych 81: 363-369.

Malhotra AK, Pinals DA, Adler CM, Elman I, Clifton A, Pickar D et al (1997). Ketamine-induced exacerbation of psychotic symptoms and cognitive impairment in neuroleptic-free schizophrenics. Neuropsychopharmacology 17: 141-150.

Malhotra AK, Pinals DA, Weingartner H, Sirocco K, Missar CD, Pickar D et al (1996). NMDA receptor function and human cognition - the effects of ketamine in healthy volunteers. Neuropsychopharmacology 14: 301-307.

Mead AN, Vasilaki A, Spyraki C, Duka T, Stephens DN (1999). AMPA-receptor involvement in c-fos expression in the medial prefrontal cortex and amygdala dissociates neural substrates of conditioned activity and conditioned reward. Eur J Neurosci 11: 4089-4098.

Miyamoto S, Duncan GE, Goff DC, Lieberman JA (2002). Therapeutics of schizophrenia. In: Davis KL, Charney D, Coyle JT, Nemeroff C (eds). Neuropsychopharmacology: The Fifth Generation of Progress. Lippincott Williams \& Wilkins: Philadelphia. pp. 775-807.

Miyamoto S, LaMantia AS, Duncan GE, Sullivan P, Gilmore JH, Lieberman JA (2003). Recent advances in the neurobiology of schizophrenia. Mol Interv 3: 27-39.

Miyamoto S, Leipzig JN, Lieberman JA, Duncan GE (2000). Effects of ketamine, MK-801, and amphetamine on regional brain 2deoxyglucose uptake in freely moving mice. Neuropsychopharmacology 22: 400-412.

Miyamoto S, Mailman RB, Lieberman JA, Duncan GE (2001). Blunted brain metabolic response to ketamine in mice lacking $\mathrm{D}_{1 \mathrm{~A}}$ dopamine receptors. Brain Res 894: 167-180.

Moghaddam B, Adams BW (1998). Reversal of phencyclidine effects by a group II metabotrophic glutamate receptor agonist in rats. Science 281: 1349-1352.

Mohn AR, Gainetdinov RR, Caron MG, Koller BH (1999). Mice with reduced NMDA receptor expression display behaviors related to schizophrenia. Cell 98: 427-436.
Monyer H, Sprengel R, Schoepfer R, Herb A, Higuchi M, Lomeli H et al (1992). Heteromeric NMDA receptors: molecular and functional distinction of subtypes. Science 256: 1217-1221.

Munoz A, Lopez-Real A, Labandeira-Garcia JL, Guerra MJ (2003). Interaction between the noradrenergic and serotonergic systems in locomotor hyperactivity and striatal expression of Fos induced by amphetamine in rats. Exp Brain Res 153: 92-99.

Nakanishi S (1992). Molecular diversity of glutamate receptors and implications for brain function. Science 258: 597-603.

Newcomer JW, Farber NB, Jevtovic-Todorovic V, Selke G, Melson AK, Hershey $\mathrm{T}$ et al (1999). Ketamine-induced NMDA receptor hypofunction as a model of memory impairment and psychosis. Neuropsychopharmacology 20: 106-118.

Ohno M, Yoshida H, Watanabe S (1994). NMDA receptormediated expression of Fos protein in the rat striatum following methamphetamine administration: relation to behavioral sensitization. Brain Res 665: 135-140.

Olney JW, Farber NB (1995). Glutamate receptor dysfunction and schizophrenia. Arch Gen Psychiatry 52: 998-1007.

Shoblock JR, Maisonneuve IM, Glick SD (2004). Differential interactions of desipramine with amphetamine and methamphetamine: evidence that amphetamine releases dopamine from noradrenergic neurons in the medial prefrontal cortex. Neurochem Res 29: 1437-1442.

Snyder SH, Aghajanian GK, Matthysse S (1972). Drug induced psychoses. Neurosci Res Prog Bull 10: 430-445.

Snyder-Keller AM (1991). Striatal c-fos induction by drugs and stress in neonatally dopamine-depleted rats given nigral transplants: importance of NMDA activation and relevance to sensitization phenomena. Exp Neurol 113: 155-165.

Turgeon SM, Case LC (2001). The effects of phencyclidine pretreatment on amphetamine-induced behavior and c-Fos expression in the rat. Brain Res 888: 302-305.

Turgeon SM, Roche JK (1999). The delayed effects of phencyclidine enhance amphetamine-induced behavior and striatal C-Fos expression in the rat. Neuroscience 91: 1265-1275.

Wang JQ, Daunais JB, McGinty JF (1994). NMDA receptors mediate amphetamine-induced upregulation of zif/268 and preprodynorphin mRNA expression in rat striatum. Synapse 18: $343-353$.

Weinberger DR, Egan MF, Bertolino A, Callicott JH, Mattay VS, Lipska BK et al (2001). Prefrontal neurons and the genetics of schizophrenia. Biol Psychiatry 50: 825-844.

Zetterstrom T, Sharp T, Marsden CA, Ungerstedt U (1983). In vivo measurement of dopamine and its metabolites by intracerebral dialysis: changes after D-amphetamine. $J$ Neurochem 41: 1769-1773. 